\section{Experimental Furcal Perforation Treated with MTA: Analysis of the Cytokine Expression}

Viviane de Paula Lima Lara1 ${ }^{1}$ Fabiano Pereira Cardoso', Luciana Carla Neves Brito $^{2}$, Leda Quercia Vieira ${ }^{3}$, Antônio Paulino Ribeiro Sobrinho¹, Taia Maria Berto Rezende $4,5,6$

\author{
'Dental School, UFMG - Universidade \\ Federal de Minas Gerais, Belo \\ Horizonte, MG, Brazil \\ ${ }^{2}$ Dental School, Universidade \\ Itaúna, Itaúna, MG, Brazil \\ ${ }^{3}$ Biological Sciences Institute, UFMG \\ - Universidade Federal de Minas \\ Gerais, Belo Horizonte, MG, Brazil \\ ${ }^{4}$ Post-graduation Program in \\ Biotechnology and Genomic Sciences, \\ UCB - Universidade Católica de \\ Brasília, Brasília, DF, Brazil \\ ${ }^{5}$ Dental School, UCB - Universidade \\ Católica de Brasília, Brasília, DF, Brazil \\ ${ }^{6}$ Post-graduation Program in \\ Health Sciences, Health Sciences \\ School, UNB - Universidade de \\ Brasília, Brasília, DF, Brazil

\begin{abstract}
Correspondence: Taia Maria Berto Rezende, Universidade Católica de Brasília, SGAN 916N, avenida W5, Campus 11, módulo C, room C-218, Brasília, DF, Brazil. Tel: +55-61-81349001. e-mail: taiambr@gmail.com
\end{abstract}

Key Words: furcal perforation, inflammatory cytokines, MTA.

\section{Introduction}

Furcal perforation is characterized by mechanical or pathologic communication between the root canal system and the external surface of the tooth (1). It should be repaired as quickly as possible with a biocompatible material able to seal the cavity, prevent bacterial invasion and inflammation development. Several sealing materials have been proposed (2), however, since 1993, mineral trioxide aggregate (MTA) is the most recommended material for repairing root and furcation perforations (3). Its main characteristics are biocompatibility, stimulation of bone and dental mineralization (1), periodontal ligament regeneration and good sealing ability (2).

In the injured sites like furcal perforations, T lymphocytes produce several pro-inflammatory cytokines (Th1) that contribute to lesion progression and bone destruction (4-6). In contrast, Th2 anti-inflammatory cytokines are responsible for healing processes by their immunosuppressive mechanisms $(7,8)$. Our research group previously demonstrated the MTA immune effects on the antibacterial activities of either M1 or M2-type macrophages (9), as well as on the adaptive immune responses (10).

Despite the MTA biocompatibility described in the literature, little is known about its immune response with time. In the present study, in order to better understand the good clinical results regarding MTA follow-up, an induced furcal mouse perforation was performed before sealing with Bios MTA (Angelus, Londrina, PR, Brazil), which is completely synthesized in laboratory with high quality control and free from contamination, especially of arsenic. The hypothesis was that MTA cytokine expression along time in periodontal tissues surrounding the sealing provides different patterns of periodontal and bone response. To evaluate the immune response pattern that takes place in furcal perforation, the expression of cytokines in periodontal tissues surrounding MTA Bios sealing of induced furcal perforations was evaluated at three sequential time points.

\section{Material and Methods Animals}

Balb/c mice aged 6-8 weeks were purchased from CEBIO (Centro de Bioterismo, ICB, UFMG, Belo Horizonte, MG, Brazil). Mice were kept in conventional animal housing with barriers and a controlled light cycle. Experimental protocol was approved by animal ethical committee (protocol number 015/2009, CETEA - UFMG).

\section{Furcal Perforation}

All experimental procedures were carried out under 
general anesthesia. Mice were injected with $100 \mathrm{mg} \cdot \mathrm{kg}^{-1}$ of ketamine hydrochloride (Dopalen; Vet-brands Animal Health, Jacareí, SP, Brazil) and $10 \mathrm{mg} \cdot \mathrm{kg}^{-1}$ of xylazine (Anasedan; Agribrands do Brasil Ltda, Paulinia, SP, Brazil). Pulp chamber of the maxillary first molar was accessed with an endodontic operative microscope (Alliance, SP, Brazil) and a $1 / 4$ carbide bur (KG Sorensen, Barueri, $\mathrm{SP}$, Brazil) coupled to a controlled rotation hand piece (Driller, São Paulo, SP, Brazil). After the pulp chamber was opened, furcal perforation was made with the same bur. In the experimental group $(n=5)$, it was sealed with MTA Bios (Ângelus), while in the control group $(n=5)$ furcal perforation was sealed with paraffin. The coronary cavity of both groups was sealed with Coltosol ${ }^{\circledR}$ (Vigodent SA, Rio de Janeiro, RJ, Brazil). All animals were euthanized by cervical dislocation. Time points were 7, 14 and 21 days after treatments.

\section{Sample Preparation}

Periapical tissue surrounding the root apices of the right and left molars was removed together with the surrounding bone in a block specimen. The gingival oral mucosa and alveolar bone were dissected and discarded. Periapical tissue $\vec{s}$ with surrounding bone was treated with Trizol reagent (Invitrogen, Carlsbad, CA, USA) for RNA extraction, as previously described (11). The reverse transcription reaction was performed according to Silva et al. (12). RNA was then stored at $-70{ }^{\circ} \mathrm{C}$.

\section{Real Time Polymerase Chain Reaction (PCR) Analysis}

Complementary DNA was synthesized using $2 \mu \mathrm{g}$ of RNA by reverse transcription as described by Silva et al. (12). The standard PCR conditions were as follows: a holding stage

Table 1. Primer sequences used in PCR reactions

\begin{tabular}{lcc}
\hline Gene & Sense and antisense & length (bp)* \\
\hline HPRT & FW: GTT GGA TAC AGG CCA GAC TTT GTT G & 162 \\
& RV: GAT TCA ACT TGC CGT CAT CTT AGG C & \\
TNF- $\alpha$ & FW: CAT CTT CTC AAA ATT CGA GTG ACA A & 171 \\
& RV: TGG GAG TAG ACA AGG TAC AAC CC & \\
IFN- & FW: TCA AGT GGC ATA GAT GTG GAA GAA & 90 \\
& RV: TGG CTC TGC AGG ATT TTC ATG & \\
RANKL & FW: CAT CCC ATC GGG TTC CCA TAA & 103 \\
& RV: CCC TTA GTT TTC CGT TGC TTA ACG AC \\
IL-4 & FW: ACA GGA GAA GGG ACG CCA T & \\
& RV: GAA GCC CTA CAG ACG AGC TCA & \\
IL-10 & FW: GGT TGC CAA GCC TTA TCG GA & 190 \\
& RV: ACC TGC TCC ACT GCC TTG CT & \\
TGF- $\beta$ & FW: TGA CGT CAC TGG AGT TGT ACG & 169 \\
& RV: GGT TCA TGT CAT GGA TGG TGC & \\
\hline
\end{tabular}

FW: forward primer; RV: reverse primer. *Amplicon length in base pairs. of $95^{\circ} \mathrm{C}$ for $10 \mathrm{~min}$; a cycling stage with 40 cycles of $95^{\circ} \mathrm{C}$ for $15 \mathrm{~s}, 60^{\circ} \mathrm{C}$ for $1 \mathrm{~min}$; and a melting curve stage of 95 ${ }^{\circ} \mathrm{C}$ for $15 \mathrm{~s}, 60{ }^{\circ} \mathrm{C}$ for $1 \mathrm{~min}$ and $95{ }^{\circ} \mathrm{C}$ for $15 \mathrm{~s}$. The primer sequences used for the analysis of IL-4, IL-10, TGF- $\beta$, TNF- $\alpha$, RANKL and IFN- $\gamma$ mRNA expression by quantitative realtime PCR are shown in Table 1. The sequences of primers were designed by using Primerexpress software (Applied Biosystems, Foster City, CA, USA) on the basis of nucleotide sequences available in the GenBank database. Real-time PCR was performed using the Step One Real-time PCR System (Applied Biosystems). In addition, the Syber-Green detection system (Applied Biosystems) was used to assay primer amplification. The housekeeping gene hypoxanthine phosphoribosyltransferase (HPRT) was used to normalize mRNA expression levels.

All samples were run in duplicate, in a $20 \mu \mathrm{L}$ reaction volume with $1 \mu \mathrm{g}$ of cDNA. Sequence Detection Software version 2.0 (Applied Biosystems) was used to analyze data after amplification. Results were obtained as threshold cycle (Ct) values. Expression levels were calculated using the $\Delta \Delta C$ method (13). The $\mathrm{Ct}$ values are expressed as the mean of two independent measurements, and the expression levels of mRNA for all samples are expressed as the ratio between the expression of the gene of interest and the expression of HPRT. All data were analyzed using the SPSS statistical program (SPSS Inc., Chicago, IL, USA).

\section{Statistical Analysis}

Shapiro-Wilk test was applied to all data to check the normal distribution, while Levene test was used to verify the data homogeneity. Then, $t$ test (for normal distribution) and Kolmogorov-Smirnov test (for non-normal distribution) were performed to compare the groups two by two. To analyze more than two independent variance samples, ANOVA (for normal distribution) and Kruskal-Wallis test (for non-normal distribution) were performed, followed by post-hoc Bonferroni test. Differences were considered statistically significant with $p$ values $<0.05$.

\section{Results}

A statistically significant increase in the TNF- $\alpha$ gene expression was observed in the experimental group from the 7 th to the 14 th day $(p<0.05)$; it was followed by a significant reduction in this cytokine expression, from the 14th to the 21st day $(p<0.05)$ (Fig. 1). The IFN- $\gamma$ and RANKL gene expressions by the experimental group presented similar response: a down-regulation from the 14 th day to the 21 st day $(p<0.05)$ (Fig. 1). There was a statistically significant down-regulation of IL-4 gene expressions when control and experimental groups were compared 
TNF- $\alpha$

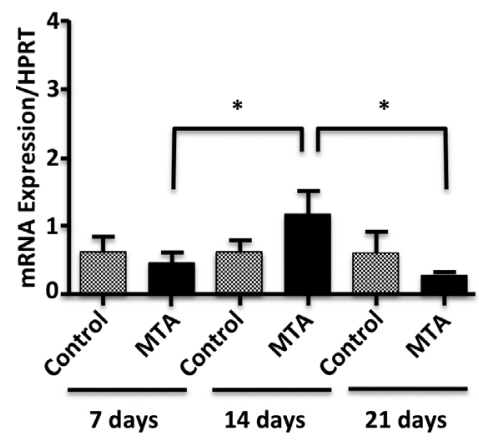

IFN- $\gamma$

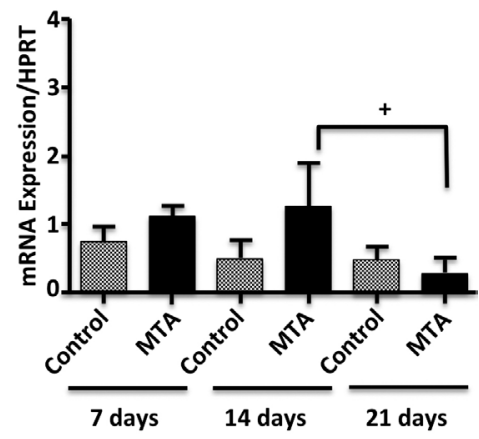

RANKL

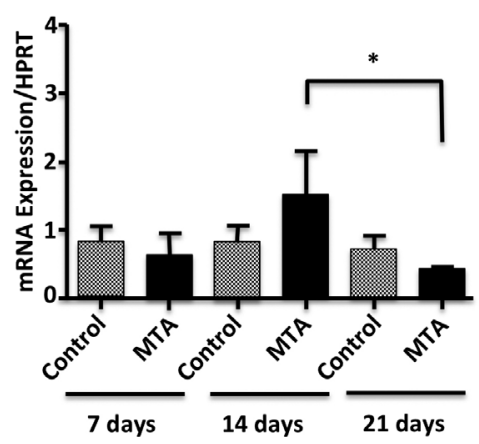

Figure 1. mRNA expression of TNF- $\alpha$, IFN- $\gamma$ and RANKL in periapical tissues of mice Balb/c subjected to experimental furcal perforation sealed with MTA or paraffin. The expression levels were determined by real time PCR and quantified by comparison with a housekeeping gene (HPRT). Bars represent the average of five experiments performed in duplicate, while the lines represent the standard error. ${ }^{*} p<0.05$, by Kruskal-Wallis test. $+p<0.05$, by ANOVA.

IL-4

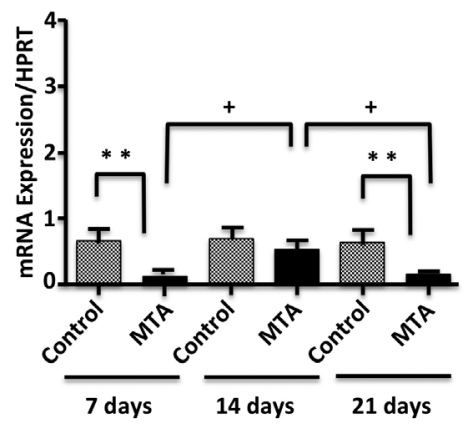

TGF- $\beta$

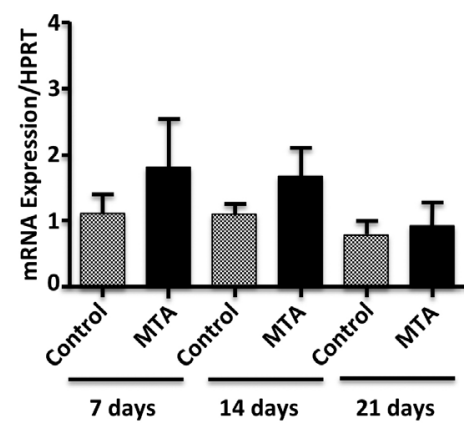

IL-10

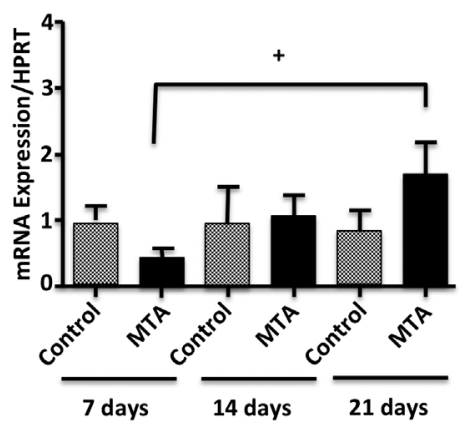

Figure 2. mRNA expression of $\mathrm{lL}-4, \mathrm{TGF}-\beta$ and $\mathrm{lL}-10$ in periapical tissues of mice Balb/c subjected to experimental furcal perforation sealed with MTA or paraffin. The expression levels were determined by real time PCR and quantified by comparison with a housekeeping gene (HPRT). Bars represent the average of five experiments performed in duplicate, while the lines represent the standard error. $+p<0.05$ by ANOVA. ${ }^{* * *} p<0.05$ by Student's $t$ test. 
at days 7 and $21(p<0.05)$. In the MTA-sealed group there was an up-regulation of IL-4 gene expression in the 14th day $(p<0.05)$, followed by its down-regulation in the 21st day $(p<0.05)$ (Fig. 2). No statistically significant differences were observed concerning TGF- $\beta$ gene expression though there was a trend to higher values for the experimental group (Fig. 2). The immunomodulatory cytokine IL-10 was significantly up-regulated on day 21 in the group treated with MTA ( $p<0.05)$ (Fig. 2).

\section{Discussion}

Most failures of sealing of root perforations occurs as a result of egression of intracanal irritants into the perirradicular tissues. MTA is currently the most recommended material for sealing off perforations due to its great biocompatibility, sealing ability, resistance to leakage, ability to set in the presence of humidity as well as its high $\mathrm{pH}$ (14). Its mechanisms of action have been described based on its composition. Structural characteristics of MTA allow a continuous hydration reaction, forming calcium hydroxide, which dissociates and releases calcium ions into the medium (15). When the released calcium ions come into contact with fluid $\vec{s}$ tissues, they produce hydroxyapatite (16). In addition, this material also had some promising results in the immune response during inflammation as well as during healing responses (17). In this study, cytokines gene expression was evaluated in periodontal tissue surrounding induced furcal perforations sealed with MTA. Cytokines usually expressed in early (TNF- $\alpha$, IFN- $\gamma$ and RANKL) and in latter (IL-10, IL-4 and TGF- $\beta$ ) immune-inflammatory stages were analyzed (18).

TNF- $\alpha$ stimulates pulp inflammation and tissue damage, recruiting lymphocytes and monocytes to local sites of infection $(2,4)$. It also stimulates endothelial cells to express adhesion molecules and secrete chemokines $(4,12)$. In the present study, no difference was observed in TNF- $\alpha$ gene expression between the periods in control group, as described by others (10). However, an up-regulation of TNF- $\alpha$ gene expression in MTA sealed groups, from the 7th to the 14th day was detected, followed by its downregulation in the 21st day. The reduction of this cytokine expression in the latter phase (21st day), may be due to regulatory effects promoted by IL-10 (4) which was upregulated at this time-point.

IFN- $\gamma$ activates macrophages, playing an important role in periapical diseases (5). In addition, it is critical for the suppression of pathologic bone resorption (6). In this study, there was no difference in its expression between the control and experimental groups, as previously described (12). However, there was a statistically significant downregulation of IFN- $\gamma$ expression levels in MTA-sealed samples in the chronic phase (21st day), similar to what was observed with other pro-inflammatory cytokines in the MTA-treated group. It is believed that IFN- $\gamma$ exerts a protective effect in bone resorption, inhibiting osteoclastogenesis and interfering with the signaling path of RANK-RANKL by the induction of TNF- $\alpha$ receptor fast degradation (19).

The differentiation and activation of osteoclasts is associated with the interaction of RANKL with its RANK receptor (20). In the present study, a RANKL downregulation from 14th to 21st day in MTA sealed samples was observed. The literature describes the MTA alkaline $\mathrm{pH}$ as an important activator for alkaline phosphatase, an important enzyme for mineralized tissue formation (21). All these results demonstrate that MTA stimulates the bone deposition in a latter phase, as previously described $(2,22)$.

TGF- $\beta$ is a cytokine that deactivates macrophages, resulting in extracellular matrix proteins deposition and tissue repair, after the local immune reactions have been controlled (23). The expression of this cytokine in periapical lesion was defined as more operative in chronic lesions (5). In spite of this, the present study did not find any statistically relevant results with respect to TGF- $\beta$ gene expression. On the other hand, a higher expression of this cytokine by human gingival fibroblasts in the presence of MTA was previously described (24).

IL-4 has an important role in the induction of humoral immune response (7). In the present study, there was a down-regulation of this cytokine expression in MTA-sealed groups on day 7 and 21 post-treatment. Conversely, Silva et al. (12) did not detect IL-4 expression in mouse pulps treated with MTA. Meanwhile, in this study was observed an up-regulation of IL-4 expression in MTA sealed groups on day 14 , followed by its reduction. These results suggest that the MTA immune modulation of the detected proinflammatory cytokines occurs in an IL-4 independent manner.

IL-10, a regulatory cytokine, is produced by APCs, T regulatory cells and other cell types (23). Its role in the inflammatory down-regulation processes in advanced lesions is partly by the induction of OPG synthesis $(5,8)$. Herein, there was no statistically significant difference in the IL-10 gene expression between the groups treated or not with MTA, as described elsewhere $(10,11)$. Moreover, when the production of this cytokine was compared among the different time points in the experimental groups, it was observed an up-regulation on day 21 in relation to day 7. This increased delayed expression of IL-10 is paralleled with the reduction of the type 1 cytokines (TNF- $\alpha$, IFN- $\gamma$ and RANKL) in the same period, suggesting that the MTAimmune modulation is IL-10 dependent, as described elsewhere (8).

Although MTA has many favorable properties that 
support its clinical use, there are also negative points, like its difficult manipulation, absence of antimicrobial activity and also its extended setting time (15). Recent studies have addressed different formulations (25) or manipulations of MTA (15), aiming at having a better MTA on the market.

Finally, little difference was observed between control and MTA groups. This difference was only observed in IL-4 production. This difference was not observed in the other cytokine productions probably due to the moderate standard deviation of all groups. In addition, other studies observed only a mild effect of MTA in cytokine production $(10,11,17)$. These results suggest that MTA induces a host protective response during different phases of the immune response. MTA up-regulated the expression of proinflammatory cytokines in the initial steps of its application, while it up-regulates IL-10 expression in a latter phase that will probably lead to tissue repair.

\section{Resumo}

0 objetivo desse artigo foi avaliar a expressão das citocinas induzidas por MTA após a perfuração experimental de furca, em camundongos. Camundongos Balb/c $(n=5)$ foram submetidos à perfuração induzida da furca do primeiro molar superior, seguido pelo selamento da mesma com MTA no lado esquerdo (grupo experimental) e com parafina no lado direito (grupo controle). Os animais foram sacrificados 7, 14 e 21 dias após o tratamento da perfuração. A expressão gênica dos níveis de IFN- $\gamma$, TNF- $\alpha$, IL-10, IL-4, TGF- $\beta$ e RANKL foram investigadas por PCR em tempo real nos dentes e tecidos adjacentes. No grupo experimental, após 7 dias, houve uma diminuição da expressão dos niveis de TNF- $\alpha$ e IL-4 comparados ao $14^{\circ}$ dia $(p<0,05)$. Nesses mesmos grupos, os níveis de mRNA de RANKL, IFN- $\gamma$ e TNF- $\alpha$ foram estatisticamente maiores após 14 dias comparados a 21 dias após o tratamento com MTA $(p<0,05)$. Os niveis de IL-10 estavam aumentados no $21^{\circ}$ dia $(p<0,05)$. A expressão de mRNA do TGF- $\beta$ não apresentou alteração estatisticamente relevante. Houve uma redução estatística da expressão gênica da IL-4 quando os grupos controle e experimental foram comparados nos dias 7 e 21 . Em conclusão, o selamento com MTA favoreceu a expressão de citocinas pró-inflamatórias na fase intermediária da resposta imuno-inflamatória $\left(14^{\circ} \mathrm{dia}\right)$. A redução dessas citocinas, na fase tardia da resposta, ocorreu provavelmente devido à imunoregulação da expressão de IL-10.

\section{Acknowledegments}

This work was supported by FAPEMIG, CAPES and CNPq. The authors wish to thank the Graduate Program of the Dental School of UFMG. LCNB is a CAPES fellow; LOV and APRS are CNPq fellows.

\section{References}

1. Holland R, Bisco Ferreira L, De Souza V, Otoboni Filho JA, Murata SS, Dezan Jr E. Reaction of the lateral periodontium of dog's teeth to contaminated and noncontaminated perforations filled with mineral trioxide aggregate. J Endod 2007;33:1192-1197.

2. Main C, Mirzayan N, Shabahang S, Torabinejad M. Repair of root perforations using mineral trioxide aggregate: a long-term study. J Endod 2004;30:80-83.

3. Lee SJ, Monsef M, Torabinejad M. Sealing ability of a mineral trioxide aggregate for repair of lateral root perforations. J Endod 1993;19:541544.

4. Zakharova M, Ziegler HK. Paradoxical anti-inflammatory actions of TNF-alpha: inhibition of IL-12 and IL-23 via TNF receptor 1 in macrophages and dendritic cells. J Immunol 2005;175:5024-5033.

5. Colic M, Gazivoda D, Vucevic D, Vasilijic S, Rudolf R, Lukic A. Proinflammatory and immunoregulatory mechanisms in periapical lesions. Mol Immunol 2009; 47:101-113.

6. Sasaki H, Balto K, Kawashima N, Eastcott J, Hoshino K, Akira S, et al.. Gamma interferon (IFN-gamma) and IFN-gamma-inducing cytokines interleukin-12 (IL-12) and IL-18 do not augment infection-stimulated bone resorption in vivo. Clin Diagn Lab Immunol 2004;11:106-110.

7. Gilmour J, Lavender P. Control of IL-4 expression in T helper 1 and 2 cells. Immunology 2008;124:437-444.

8. Sasaki H, Hou L, Belani A, Wang CY, Uchiyama T, Müller R, et al.. IL-10, but not IL-4, suppresses infection-stimulated bone resorption in vivo. J Immunol 2000;165:3626-3630.

9. Rezende TMB, Vargas DL, Cardoso FP, Ribeiro Sobrinho AP, Vieira LQ. Effect of mineral trioxide aggregate on cytokine production by peritoneal macrophages. Int Endod J 200538:896-903.

10. Rezende TMB, Vieira LQ, Ribeiro Sobrinho AP, Oliveira RR, Taubman $M A$, Kawai T. The influence of mineral trioxide aggregate on adaptive immune responses to endodontic pathogens in mice. J Endod 2008;34:1066-1071.

11. Silva MJ, Sousa LM, Lara VPL, Cardoso FP, Júnior GM, Totola AH, et al.. The role of iNOS and PHOX in periapical bone resorption. J Dent Res 2011;90:495-500.

12. Silva $M J B$, Vieira $L Q$, Ribeiro Sobrinho AP. The effects of mineral trioxide aggregates on cytokine production by mouse pulp tissue. Oral Surg Oral Med Oral Pathol Oral Radiol Endod 2008;105:70-76.

13. Schmittgen TD, Livak KJ. Analyzing real-time PCR data by the comparative C (T) method. Nat Protoc 2008;3:1101-1108.

14. Koh ET, McDonald F, Pitt Ford TR, Torabinejad M. Cellular response to mineral trioxide aggregate. J Endod 1998;24:543-547.

15. Jacinto RC, Linhares-Farina G, Sposito OD, Zanchi CH, Cenci MS. Influence of $2 \%$ chlorhexidine on $\mathrm{pH}$, calcium release and setting time of a resinous MTA-based root-end filling material. Braz Oral Res 2015;29:1-6

16. Camilleri J, Sorrentino F, Damidot D. Investigation of the hydration and bioactivity of radiopacified tricalcium silicate cement, Biodentine and MTA Angelus. Dent Mater 2013;29:580-593.

17. Braga JM, Oliveira RR, Martins RC, Martins RC, Ribeiro Sobrinho AP. The effects of a mineral trioxide aggregate-based sealer on the production of reactive oxygen species, nitrogen species and cytokines by two macrophage subtypes. Int Endod J 2014;47:909-919.

18. Maciel KF, Brito LCN, Tavares WLF, Moreira G, Nicoli JR, Vieira LQ, et al.. Cytokine expression in response to root canal infection in gnotobiotic mice. Int Endod J 2012;45:345-362

19. Takayanagi H, Sato K, Takaoka A, Taniguchi T. Interplay between interferon and other cytokine systems in bone metabolism. Immunol Rev 2005;208:181-193.

20. Boyle WJ, Simonet WS, Lacey DL. Osteoclast differentiation and activation. Nature 2003;423:337-342.

21. Duarte MD, Alves de Aguiar K, Zeferino MD, Vivan RR, OrdinolaZapata R, Tanomaru-Filho $M$, et al.. Evaluation of the propylene glycol association on some physical and chemical properties of mineral trioxide aggregate. Int Endod J 2012;45:565-570.

22. Schwartz RS, Mauger M, Clement DJ, Walker III WA. Mineral trioxide aggregate: a new material for endodontics. J Am Dent Assoc 1999;130:967-975

23. Hahn CL, Liewer FR. Update on the adaptive immune responses of the dental pulp. J Endod 2007;33:773-781.

24. Guven G, Cebreli ZC, Ural A, Serdar MA, Basak F. Effect of mineral trioxide aggregate cements on transforming growth factor 1 and bone morphogenetic protein production by human fibroblasts in vitro. J Endod 2007;33:447-450.

25. Mirhadi H, Moazzami F, Safarzade S. The effect of acidic on microleakage of mineral trioxide aggregate and calcium-enriched mixture apical plugs. Iran Endod J 2014;9:257-260. 